\begin{tabular}{|c|c|}
\hline $\begin{array}{c}\text { Возможность включать в тест вопросьь } \\
\text { различных типов, с различной степенью } \\
\text { сложности }\end{array}$ & \\
\hline Возможность добавлять аудио, видео вставки в & \\
задания
\end{tabular}

1. Черноскова Ю. Ю. Системы разработки online тестов и организации тестирования // Гаудеамус. 2012 . №20. URL: https://cyberleninka.ru/article/n/sistemy-razrabotki-online-testov-i-organizatsii-testirovaniya .

2. Корнева О.Е., Рожина И.В., Саакян М.К., Рожина Д.С. Использование сетевых сервисов для организации самостоятельной деятельности учащихся // Наука и перспективы. 2017. №1. URL: https://cyberleninka.ru/article/n/ispolzovanie-setevyh-servisov-dlya-organizatsii-samostoyatelnoy-deyatelnostiuchaschihsya.

\title{
Белых А.C. \\ Объектные фразеологизмы со значением одушевленности в английском языке
}

Белгородский государственный исследовательский университет НИУ «БелГУ» (Россия, Белгород)

doi: 10.18411/trnio-01-2022-123

Научный руководитель: Дрыгина Ю.А.

\section{Аннотация}

Исследование основано на семантическом и грамматическом анализе фразеологических единиц с зоонимическим компонентом в английском языке, собранных методом сплошной выборки из англо-русских фразеологических словарей А.В. Кунина. В сфере фразеологии семантические категории одушевленности и личности тесно связаны с действительностью. Приведенная классификация основана на одушевленности, которая раскрывает реальность мира одушевленных вещей.

Ключевые слова: фразеологизм, фразеологические единицы, семы, одушевленность, зооним, антропоним, лексема, антропономинация.

\section{Abstract}

The study is based on the semantic and grammatical analysis of phraseological units with a zoonymic component in the English language, collected by a continuous sampling method from English-Russian phraseological dictionaries by Professor A.V. Kunin. In the field of phraseology, the semantic categories of animateness and personality are closely related to reality. Our classification is based on animateness, which reveals the reality of the world of animate things.

Keywords: phraseology, phraseological units, animateness, semes, zoonym, anthroponym, lexeme, anthroponomination.

По мнению А.В. Кунина, «фразеологизм - это устойчивое сочетание слов с полностью или частично переносным значением» (Кунин, 2005: 11-12). Это определение хорошо подходит как для теоретического анализа, так и для практической идентификации. Его англо-русский фразеологический словарь (около 25000 единиц с текстовыми иллюстрациями) получил высокую оценку (Кунин, 2005: 8). Определение Кунина включает в себя два неотъемлемых свойства: стабильность и переносное значение, которые отличают эти единицы от свободных словосочетаний, а также от устойчивых выражений, не имеющих переносного значения.

Существительные и прилагательные играют важную роль в построении семантики фразеологических единиц с зоонимическим компонентом в английском языке. Существительные, являющиеся основными грамматическими компонентами, обеспечивают семантическую структуру фразеологизмов с категориальной семой объектности и 
подкатегориальными семами одушевленности и личности. Остальные грамматически подчиненные компоненты образуют групповые и отдельные семы.

Из 209 объектных фразеологизмов 11 обозначают одушевленные предметы, и это выражается в их лексикографическом описании: the cat's meow (кошачье мяуканье) «кто-то или что-то чудесное или замечательное»; a Trojan horse (троянский конь) «кто-то или что-то намеревавшееся победить или подорвать изнутри, обычно обманным путем»; a sacred cow (священная корова) «человек или вещь, которую никогда не критикуют, не смеют и не оскорбляют, даже если она заслуживает такого обращения»; the big bad wolf (большой злой волк) «угрожающий или зловещий человек или вещь» и т. д.

Основной грамматический компонент обычно выражается такими зоонимами, как лошадь, корова, утка, муха, волк, что обеспечивает семантическую структуру фразеологизмов с категориальной семой объектности и подкатегориальными семами одушевленности и личности.

Около половины всех предметных фразеологизмов с зоонимическим компонентом (всего 101 единица) обозначают живые существа. Анализ их лексикографических определений и контекстной реализации показал, что их можно разделить на три семантических кластера: 1) единицы, номинирующие людей, или «антропонимы»; 2) подразделения, номинирующие животных; 3) юниты, выдвигающие мифических существ.

Обладая подкатегориальной семой анимации, объектные фразеологизмы с зоонимическими компонентами называют человека в подавляющем большинстве случаев употребления. Выделено 90 единиц, обозначающих людей. Их принято называть «антропонимами», или, по терминологии профессора Е.Р. Ратушной, их можно назвать «антропономинациями» (Ратушная, 2000: 15): a dirty dog (грязный пес), «низкий и подлый человек»; a willing horse (рабочая лошадка) «человек, готовый много работать»; $a$ wolf in sheep's clothing (волк в овечьей шкуре) «опасный человек, притворяющийся безобидным»; $a$ bull in a china shop (слон в посудной лавке) «крайне неуклюжий человек»; a fighting cock (бойцовый петух) «драчливый человек»; a big bug (большая шишка) «важный человек»; а fish out of water (рыба вытащенная на берег) «тот, кто не чувствует себя комфортно в новой среде» и т. д.

В рамках этого семантического кластера также можно найти фразеологические единицы, обозначающие группу людей или единство: Kilkenny cats (коты Килкенни) «люди, которые неустанно борются до конца»; birds of a feather (птицы одного полета) «люди, похожие по характеру»; a hen party (девичник) «группа женщин на вечеринке для женщины, которая скоро собирается выйти замуж» и т. д (Кунин, 1984: 23-187).

Грамматически главный компонент выражается зоонимом, который в силу своего прямого лексического значения формирует категориальную и подкатегорическую семантику всего фразеологизма. Подкатегориальная сема человека проявляется в семантической структуре единицы для идентификации человека, характеризующегося некоторыми определенными чертами.

Группа фразеологизмов, обозначающих животных, в основном птиц, включает 9 единиц: the king of beasts “a lion” (царь зверей «лев»); the bird of Jove (птица Юпитера) «любая из различных крупных зорких дневных хищных птиц, известных своими широкими крыльями и сильным парящим полетом»; the bird of Juno (птица Юнона) «очень большой наземный фазан из юго-восточной Азии, часто выращиваемый как декоративная птица»; the bird of Minerva (птица Минерва) «ночная хищная птица с ястребиным клювом и когтями и большой головой с обращенными вперед глазами»; a bird of paradise (райская птица) «любая из множества ярких пернатых птиц Новой Гвинеи»; a bird of prey (хищная птица) «птица, такая как орел или ястреб, убивающая и поедающая мелких птиц и животных»; the king of birds (царь птиц) «орел»; the bird of peace (птица мира) «образное имя голубя»; Mother Carey's chicken (цыпленок мамы Кэри) «буревестник» (Кунин, 1984: 32-89).

Лексема «птица» как компонент фразеологизмов обеспечивает их семантическую структуру с категориальными и подкатогорическими семами. В некоторых частях мы находим имена древнеримских богов: Юпитер, также известный как Юпитер - бог неба, 
дневного света и грома, а также царь богов в древнеримской религии и мифологии. Его опознавательным орудием является молния, а его основным священным животным является орел; Юнона, жена Юпитера, защитница и специальный советник государства, богиняпокровительница всех женщин Рима, богиня брака и материнства, ее священным животным был павлин. Минерва - римская богиня мудрости и стратегической войны, покровительница искусства, торговли и стратегии, а также девственная богиня музыки, поэзии, медицины, мудрости, торговли, ткачества и ремесел, ее часто изображают вместе с ней. священное существо, сова, которая символизирует ее связь с мудростью и знаниями. существ.

Существовали только две фразеологические единицы, обозначающие мифических

1) The Arabian bird (арабская птица) «феникс, сказочная птица, которая после жизни в пять или шесть столетий сжигает себя на костре и восстает из пепла, чтобы начать новый цикл лет: часто эмблема бессмертия или возрожденного идеализма или надежды».

Компонент «птица» актуализирует семы объектности, одушевленности и безличности. Компонент «арабский» актуализирует сему «относящийся к Аравии» и обозначает происхождение мифической птицы. Феникс ассоциируется с Солнцем и изображается во многих культурах как обладающий способностью обрести новую жизнь, возродившись из пепла своего предшественника. Это символ обновления и бессмертия. В исторических записях феникс мог символизировать обновление в целом, а также солнце, время, Империю, посвящение, воскресение, жизнь в небесном Раю, Христа, Марию, девственность, исключительного человека и некоторые аспекты христианской жизни.

2) Lamb of God (Агнец Божий) «титул, данный Христу в Новом Завете, вероятно, в связи с его жертвенной смертью». Это происходит из Библии. Хотя в основном оно используется как другое имя Иисуса Христа, оно также может обозначать смиренного человека с чистой душой. Агнец Божий один из главных христианских символов, в первую очередь католической церкви (Попов, 1981: 53).

Таким образом, объектные фразеологические единицы по количеству превосходят любой другой семантико-грамматический тип фразеологических единиц с зоонимическими компонентами в английском языке. Этот факт подчеркивает общую тенденцию носителей английского языка обозначать вещи, вещества и явления действительности с помощью описательных языковых единиц для особого эмоционального эффекта.

$$
* * *
$$

1. К Кунин, А. В. Курс фразеологии современного английского языка / А.В. Кунин. - М.: Феникс +, $2005 .-488$ с.

2. Кунин А.В. Англо-русский фразеологический словарь. - Изд. 4-е, переработанное и дополненное. - М., 1984.

3. Лебединская, В.А., Пермякова Е.А. Роль словных компонентов в формировании фразеологических значений [текст] / Сергеевские чтения, выпуск 3. - Курган, 1999 25-27 с.

4. Попов Р.Н. Фразеологизмы современного русского языка с архаичными значениями и формами слов. - М., 1981. $-410 \mathrm{c}$.

5. Ратушная, Е.Р. Семантические свойства фразеологизмов, обозначающих человека по внешним признакам [текст] / Сергеевские чтения, выпуск 3. Курган, 2000. - 341 с.

Белько Е.С.

Использование системы электронного обучения при организации государственной итоговой аттестации в высшей школе: опыт и перспективы

Сибирский федеральный университет (Россия, Красноярск)

doi: 10.18411/trnio-01-2022-124

Аннотация

Электронное обучение является одним из факторов инновационного развития современного образования в целом и вузовского образования, в частности. Сегодня все 